\title{
DIAGNOSIS OF OVERTRAINING SYNDROME
}

\author{
DIAGNÓSTICO DA SÍNDROMEDO OVERTRAINING
}

DIAGNÓSTICO DEL SIINDROMEDEL OVERTRAINING

ReVieW ArticLes

ARTIGOS DE REVISÃo

Fellipe Pinheiro Savioli? (physician)

Thairon Mesquita Medeiros² (physician)

Sergio Luiz Camara Jr ${ }^{3}$ (physician)

Elizabeth Peres Biruel ${ }^{1}$ (historian and librarian)

Carlos Vicente Andreoli4 (physician)

1. Universidade Federal de São Paulo (Unifesp), São Paulo, SP, Brazil. 2. Hospital do Trauma Ortopédico, São Luiz, MA, Brazil.

3. Hospital Evangélico de Curitiba, Curitiba, PR, Brazil.

4. Universidade Federal de

São Paulo (Unifesp), Sports

Traumatology Center, São Paulo,

SP, Brazil.

\section{Correspondence:}

Rua Oscar Freire, 1500, ap 142, São Paulo, SP, Brazil. 05409-010 fellipesavioli@gmail.com or fpsavioli@yahoo.com.br

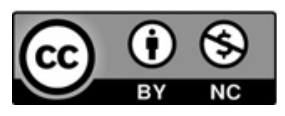

\begin{abstract}
Overtraining syndrome (OTS) is a condition associated with diminished sports performance due to an increase in the volume and/or intensity of physical activity without adequate rest, and/or due to an inadequate diet. The condition often involves hormonal, nutritional, emotional, muscle, immune and neurological imbalances. Epidemiology varies considerably, affecting both sexes in different age groups. Diagnosis is still a challenge, as the syndrome resembles different diseases. The lack of specific symptoms requires a meticulous investigation in all athletes, which is often multidisciplinary. OTS can have an important repercussion on sports performance and on the quality of life of athletes. Methods: This is a mapping of scientific literature along the lines of the Systemic Review. The databases investigated were: MEDLINE and Latin American and Caribbean Health Sciences Literature - LILACS and EMBASE, in addition to printed documents. Studies describing OTS were included, prioritizing articles that report the efficacy of the different diagnostic methods, be they clinical, laboratory, or imaging. Results: We found 83 articles, of which 30 were selected. Conclusion: The only symptom present in all the different forms of manifestation of OTS is loss of performance. However, some tests assessing oxidative stress levels seem promising, even though they are not specific. Revision article.
\end{abstract}

Keywords: Burnout, professional.

\section{RESUMO}

A síndrome do overtraining (SO) é uma afeç̧ão associada à diminuição da performance esportiva decorrente do aumento do volume e/ou intensidade de atividades físicas sem repouso adequado elou de dieta inadequada. $E$ comum encontrarmos alterações hormonais, nutricionais, emocionais, musculares, imunológicas eneurológicas. A epidemiologia ébastante diversa, acometendo ambos os sexos em diferentes faixas etárias. O diagnóstico ainda éum desafio, devido à similaridade com diferentes doenças. A falta de sintomas específicos exige investigação criteriosa em todos os atletas, muitas vezes multidisciplinar. A SO pode ter repercussão importante na performance esportiva e também na qualidade de vida do atleta. Métodos: Trata-se de um mapeamento da literatura científica no rigor da Revisão Sistemática. As bases de dados pesquisadas foram: MEDLINE e Literatura Latino-Americana e do Caribe em Ciências da Saúde - LILACS e EMBASE, além de documentos impressos. Foram incluidos estudos que descreveram a SO, priorizando os artigos que relatavam a eficácia dos diferentes métodos diagnósticos, sejam eles clínicos, laboratoriais ou de imagem. Resultados: Foram encontrados 83 artigos, dos quais 30 trabalhos foram selecionados. Conclusão: 0 único sintoma presente em todas as diferentes formas de manifestação de 50 é a perda de desempenho. O diagnóstico ainda é um grande desafio, pela falta de exames especificos. Porém, alguns exames que avaliam nivel de estresse oxidativo parecem ser promissores, mesmo não sendo específicos. Estudo de revisão.

\section{Descritores: Esgotamento profissional.}

\section{RESUMEN}

El sindrome de Overtraining (SO) es una condición de rendimiento deportivo disminuido debido a un aumento en el volumen y/o intensidad del ejercicio sin un descanso adecuado o debido a una ingesta de energía inadecuada. Es común encontrar desequilibrios hormonales, nutricionales, emocionales, musculares, inmunológicos y neurológicos. Se ve con mayor frecuencia en atletas de resistencia como nadadores, ciclistas, corredores y triatletas. Se estima que la prevalencia del sindrome de overtraining (SO) es aproximadamente del $30 \%$ para los atletas de resistencia no elite, y del 60\% para los atletas de elite. Por lo tanto, debido a la gravedad de los síntomas y al deterioro de la calidad de vida, se debe realizar una investigación adecuada en todos los atletas de Endurances. Sin embargo, un diagnóstico preciso puede ser un desafío debido a su similitud con otras afecciones, tales como: broncoespasmo inducido por ejercicio, mononucleosis infecciosa, sueño insuficiente, anemia, ansiedad de rendimiento, ingestión no adecuada de carbohidratos o proteínas, infección de las vías respiratorias superiores, trastorno del estado de ánimo, estrés psicosocial, abstinencia de cafeína o alergias ambientales. El objetivo de este trabajo es evaluar todo tipo de diagnóstico (clínico, de laboratorio o de imagen) para permitir un diagnóstico preciso para evitar complicaciones del SO. Artículo de revisión

Descriptores: Agotamiento Profesional. 


\section{INTRODUCTION}

Professional athletes are required to push the limits of their physical performance on a daily basis. Good performance results are required from the following individuals: the athletes themselves, the coach, the club represented by the athletes, sponsors, and sometimes the athletes' family. If training is not conducted regularly, and without consideration for exercise volume and intensity, a balanced diet, and adequate rest, the athlete may develop overtraining syndrome (OS). Nowadays, OS does not affect professional athletes exclusively; many amateur athletes undertake hard physical training to achieve higher goals in competitions or to participate in world championships in a variety of sports, which may lead to metabolic imbalances.

There are several definitions of OS and overreaching (OR); however, this study utilizes the definition proposed by Kreider et al. ${ }^{1}$

Overreaching is a type of physical activity followed by a small period of decreased performance, which may or may not be associated with physiological changes, with recovery/improvement of performance a few days later. Some authors subdivide overreaching into functional and non-functional categories. Functional overreaching occurs when overcompensation is reached after an adequate period of rest, with improvement of performance. Non-functional overreaching is the loss or stagnation of performance, lasting for a few weeks or months. In the latter state, hormonal alterations are usually present.

Overtraining is a physical activity followed by a long period of decreased performance, which may or may not involve physiological changes, with recovery/improvement of performance a few weeks or months later (Figures 1 and 2).

According to several authors, the difference between OR and OS is the time required to recover and achieve previous performance., ${ }^{2,3}$

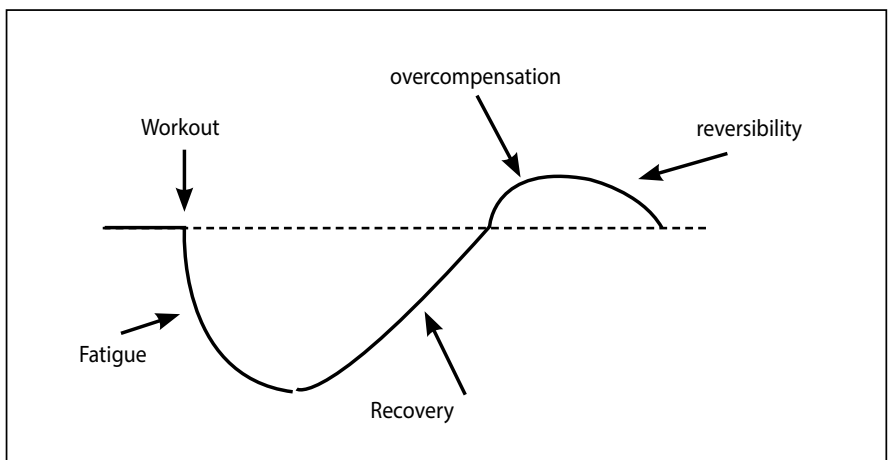

Figure 1. After a workout, performance decreases for a certain period, and athletes should have an adequate diet and rest to recover and to consequently overcompensate. Compensation is a period of performance improvement, when athletes should exercise again. If a workout is not conducted during the overcompensation period, then performance will not improve, and reversal will consequently occur. If a workout is conducted during the recovery period, performance will decline.

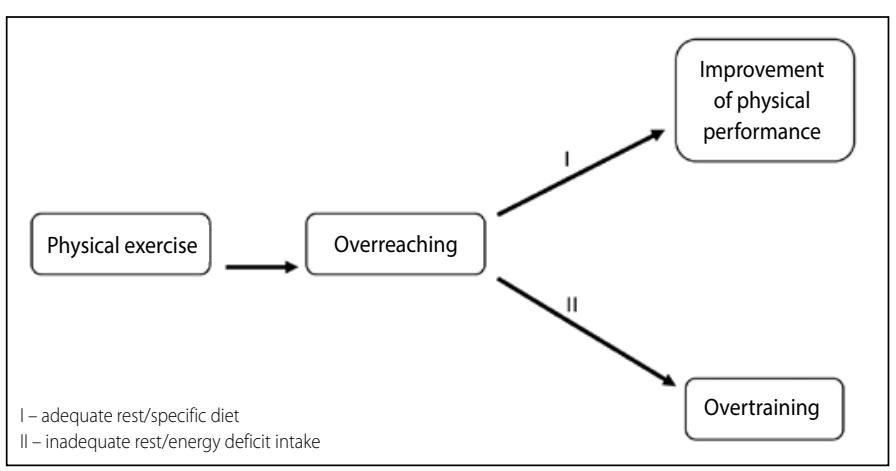

Figure 2. With adequate rest and diet after a workout (volume and intensity), performance will increase in the next workout

\section{Incidence}

Studies addressing OS incidence are scarce and contradictory. Some authors address functional overreaching cases as non-functional overreaching or OS cases.

Matos et al. observed that a third of young English athletes with an average age of 15.1 years showed overtraining or non-functional overreaching. ${ }^{4}$ Koutedakis et al. found a greater OS incidence in men than in women, particularly during the pre-competition period. ${ }^{5}$ Halson et al. also found a greater OS incidence in men, ${ }^{3}$ whereas Kreher et al. observed that more women were affected. ${ }^{6}$

In addition, other studies demonstrated high OS recurrence. Raglin et al. demonstrated that $91 \%$ of university swimmers diagnosed with OS had the same condition after 3 years.?

\section{Physiopathology}

Several hypotheses have been proposed for OS, and all have their strengths and weaknesses. The main hypotheses proposed are the following: glycogen, central fatigue or branched-chain amino acids (BCAA), glutamine, oxidative stress, autonomic nervous system, hypothalamic axis, and cytokines.

Glycogen hypothesis: when the muscle concentration of glycogen is low, sufficient energy is not available to conduct intensive training. The decrease in the glycogen stock increases oxidative processes in other energy substrates, reducing the branched-chain amino acid concentration, which is involved in the synthesis of central neurotransmitters. ${ }^{6,8}$ Athletes who have inadequate carbohydrate intake have a greater chance of becoming fatigued. However, they do not present with clinical manifestations consistent with OS. Furthermore, some athletes with OS have adequate carbohydrate intake. For these reasons, some authors disapprove of this hypothesis. ${ }^{9}$

Central fatigue or branched-chain amino acids hypothesis: tryptophan, an essential amino acid and precursor to serotonin, competes directly with BCAA (leucine, isoleucine, and valine) in the blood brain barrier. Physical exercise decreases the BCAA amount due to oxidation, allowing the influx of tryptophan into the brain and increasing serotonin concentration. This extreme increase in serotonin induces a state of fatigue, mood swings, and sleep disorders. Some athletes who have used serotonin reuptake inhibitors felt fatigued and exhibited decreased performance. ${ }^{10}$ This hypothesis is criticized by many authors since it is not possible to quantify mood swings and fatigue, and it is difficult to distinguish between the effects of central and peripheral serotonin.

Glutamine hypothesis: physical activity increases the rates of oxidation of glutamine. Due to its depletion, the immune system changes its function, leaving the athlete more susceptible to infections, particularly in the upper respiratory tract, which has a close relationship with OS.11 Some authors argue that serum glutamine levels do not correspond to glutamine bioavailability in the body; thus, glutamine depletion may not be responsible for a number of other symptoms described by athletes with OS.12

Oxidative stress hypothesis: with increased exercise volume and intensity, there is an increase in the production of free radicals, which leads to tissue injury and fatigue. The inflammatory state presented by some athletes may be related to free radicals and antioxidant imbalance. Athletes with OS generally have alterations in carbonylated serum protein, nitrotyrosine, and malondialdehyde. Carbonylated proteins and nitrotyrosine are protein oxidation indicators, whereas malondialdehyde is a fat peroxidation indicator.

Autonomic nervous system hypothesis: some authors suggest that there is parasympathetic predominance over the sympathetic nervous system, with decreased adrenal activity associated with increased 
adrenocorticotropin hormone (ACTH) levels. However, catecholamine measurements in some athletes, especially those performed at night, provide evidence against this hypothesis.

Hypothalamic axis hypothesis: alterations in the hypothalamic axis, particularly in the hypothalamic-pituitary-adrenal and the hypothalamicpituitary-gonadal axes, ${ }^{5,6,13}$ cause changes in the levels of cortisol, testosterone, ACTH, and consequently, estrogen. These alterations may explain the increased incidence of infections in the upper respiratory tract, and the decreased inflammation observed in tests. One hypothesis is that prolonged physical exercise may cause some type of resistance to ACTH in the suprarenal glands, resulting in diminished serum cortisol. This may also cause an initial increase ACTH level, which may reach normal levels as time progresses. However, these findings may be confused with Addison's disease. ${ }^{14}$ Some studies report that athletes who have OS for a long time exhibit a clinical picture similar to that of Addison's disease due to the non-responsiveness of the adrenal gland, even when training has finished.

Cytokines hypothesis: The increase in inflammatory cytokine production, including IL-1 $\beta, I L-6$ (which may not be inflammatory in certain situations), IL-10, and tumor necrosis factor alpha (TNF-a), in the resting period of endurance athletes may indicate overtraining. However, studies assessing this situation throughout longer periods of time are virtually absent, and athletes with OS who present normal levels of cytokines are frequently observed.

\section{Clinical picture}

the increased heart rate during resting has been described as a sign of OS. ${ }^{15,16}$ Nevertheless, a large number of studies do not confirm this alteration. ${ }^{17,18,19}$ It is a very non-specific sign since it may indicate some form of infection. In addition, some authors sub-classify OS into sympathetic and parasympathetic categories, and therefore, this sign would be valid for just one of the OS forms. Other authors believe that sympathetic OS is the preceding stage of parasympathetic OS, with OS comprising an initial period of increased production of cortisol and catecholamines, causing sleep disorders. There is also a greater probability of infections, followed by a period of resistance to all these biochemical changes. If the parasympathetic stage is reached, the treatment will be longer and more difficult.

Heikki Ruscko described a diagnostic test for overtraining based on heart rate (HR) during rest by measuring the patient's HR at the horizontal dorsal decubitus position. Subsequently, the patient is told to stand up, and HR measurements are again conducted 15,90, and 120 seconds later. If an increase by at least 10 heartbeats in the HR is observed, the patient is diagnosed with OS.

Another possible approach for diagnosing OS involves evaluation of the athlete's performance using the Borg Scale. Progressive levels of training intensity are simulated, corresponding to the previous performance when the athletes did not present any OS symptom. Then, athletes are asked to report the perceived exertion level for comparison. The lactate dosage may be analyzed at the end to increase the reliability of the test. ${ }^{20}$

Mood swings are a frequent part of OS, which normally occur before the loss of performance. Adynamia may be present, and some athletes may present with a clinical picture similar to depressive disorders. Sleep disorders are also usually present. ${ }^{21}$

Therefore, no sign or symptom is specific to OS, and a thorough examination involving different medical specialties should be conducted to exclude other conditions that present clinical pictures similar to that of OS. The following are among such conditions: asthma, thyroid disorders, psychiatric disorders, adrenal gland changes, diabetes, anemia, infections, inadequate caloric intake, neoplasia, rheumatic diseases, kidney diseases, and liver diseases.

\section{Biochemical/hormonal changes}

hemogram results and tests for erythrocyte sedimentation rate and levels of C-reactive protein, creatine phosphokinase, urea, creatinine, liver enzymes, glycose, ferritin, sodium, and potassium cannot be used to diagnose OS; however, they provide important information regarding the athlete's current health and for excluding other diagnoses. Serology tests may be required according to the athlete's history.

The relationship between testosterone and cortisol during rest is used by many doctors as an indicator of overtraining. This relationship decreases when there is an increase in the exercise volume and/or intensity; therefore it indicates the current physiological state and may not be used to diagnose OS.

Many authors agree that OS is associated with the adaptability of hypothalamic axes, especially the hypothalamic-pituitary-adrenal axis. 22,23,24,25 However, tests such as those for morning serum cortisol and 24-hr urinary cortisol concentration do not provide important information regarding OS. ${ }^{26,27}$ There is also a lack of consensus regarding tests involving catecholamines, including plasma catecholamine, or any other urinary measurement. ${ }^{28}$

Measurement of salivary immunoglobulin A levels was also ineffective for diagnosing OS. Salivary immunoglobulin A level may be altered in upper respiratory tract infections, which is a frequent condition in athletes. ${ }^{29}$

Other laboratory tests may be promising, such as the relation reduced/oxidized glutathione. Glutathione is an endogenous antioxidant, which neutralizes free radicals mainly produced by the mitochondria. These tests can be used to assess a person's current state of health and may be altered in neurodegenerative diseases, such as Alzheimer's and Parkinson's disease. Urinary isoprostane levels may also provide important information since it is a substance produced during the reaction between free radicals and arachidonic acid (cellular membrane), and is related to fat oxidation, which also indicates an oxidative stress state. ${ }^{30}$

\section{CONCLUSION}

There are no unique laboratory tests or pathognomonic findings during physical examinations that can confirm the diagnosis of OS. A detailed history on diet, exercise intensity and volume, and duration of rest is required, as well as an evaluation of the athlete's current emotional situation. A detailed physical examination is also required. The above-mentioned laboratory tests should be requested and cardiovascular tests should be considered. Generally, diverse symptoms may be present and may be non-specific, with cases of OS symptomology differing between athletes. Examination of athletes by different medical professionals is often required. However, all athletes with OS show decreased performance, a fact not considered by many studies, which based their research only on biochemical/hormonal alterations that are frequently considered within normal parameters. Therefore, diagnosing OS remains a challenge since it may often have a clinical presentation similar to that of other conditions.

All authors declare no potential conflict of interest related to this article. 


\section{REFERENCES}

1. Kreider R, Fry AC, O'Toole M. Overtraining in sport: terms, definitions, and prevalence. In:Kreider R, Fry AC, O'Toole M, editors. Overtraining in sport. Champaign (IL): Human Kinetics; 1998. p. VII-IX.

2. Budgett R, Newsholme E, Lehmann M, Sharp C, Jones D, Jones T, et al. Redefining the overtraining syndrome as the unexplained underperformance syndrome. Br J Sports Med. 2000;34:67-8

3. Halson $S L$, Jeukendrup AE. Does overtraining exist? An analysis of overreaching and overtraining research. Sports Med. 2004;34(14):967-81.

4. Matos NF, Winsley RJ, Williams CA. Prevalence of nonfunctional overreaching/overtraining in young English athletes. Med Sci Sports Exerc. 2011;43(7):1287-94.

5. Koutedakis Y, Sharp NC. Seasonal variations of injury and overtraining in elite athletes. Clin J Sport Med. 1998;8(1):18-21.

6. Kreher JB, Schwartz JB. Overtraining syndrome: a practical guide. Sports Health. 2012;4(2):128-38.

7. Raglin J. Overtraining and staleness: psychometric monitoring of endurance athletes. In: RN Singer, M Murphey, LK Tennant, editors. Handbook of Research on Sport Psychology. New York: Macmillan; 1993. p. 840-50.

8. Hiscock N, Pedersen BK. Exercise-induced immunodepression-plasma glutamine is not the link. J Appl Physiol (1985). 2002;93(3):813-22

9. Armstrong LE, VanHeest JL. The unknown mechanism of the overtraining syndrome: clues from depression and psychoneuroimmunology. Sports Med. 2002;32(3):185-209.

10. Budgett R, Hiscock N, Arida RM, Castell LM. The effects of the 5-HT2C agonist m-chlorophenylpiperazine on elite athletes with unexplained underperformance syndrome (overtraining). Br J Sports Med. 2010;44(4):280-3.

11. Halson SL, Lancaster Gl, Jeukendrup AE, Gleeson M. Immunological responses to overreaching in cyclists. Med Sci Sports Exerc. 2003;35(5):854-61

12.Meeusen R, Duclos M, Foster C, Fry A, Gleeson M, Nieman D, et al. Prevention, diagnosis, and treatment of the overtraining syndrome: joint consensus statement of the European College of Sport Science and the American College of Sports Medicine. Med Sci Sports Exerc. 2013;45(1):186-205.

13. Smith LL. Cytokine hypothesis of overtraining: a physiological adaptation to excessive stress? Med Sci Sports Exerc. 2000;32(2):317-31.

14. Brooks K, Carter J. Overtraining, Exercise, and Adrenal Insufficiency. J Nov Physiother. 2013;3(125)

15. Dressendorfer $\mathrm{RH}$, Wade $\mathrm{CE}$, Schaff JH. Increased heart rate in runners: a valid sign of overtraining? Physician Sportsmed. 1985;13(8):77-86.
16. Stone MH, Keith RE, Kearney JT, Fleck SJ, Wilson GD, Triplett NT. Overtraining: a review of the signs and symptoms and possible causes. J Appl Sport Sci Res. 1991;5(1):35-50.

17. Fry RW, Morton AR, Garcia-Webb P, Crawford GP, Keast D. Biological responses to overload training in endurance sports. Eur J Appl Physiol. 1992;64(4):335-44

18. Lehmann M, Gastmann U, Petersen KG, Bachl N, Seidel A, Khalaf AN, et al. Training - over- training: performance, and hormone levels, after a defined increase in training volume versus intensity in experienced middle- and long-distance runners. Br J Sports Med. 1992;26(4):233-42.

19. Snyder AC, Kuipers H, Cheng B, Servais R, Fransen E. Overtraining following intensified training with normal muscle glycogen. Med Sci Sports Exerc. 1995;27(7):1063-70.

20. Jeukendrup AE, Hesselink MKC, Snyder AC, Kuipers H, Keizer HA. Physiological changes in male competitive cyclists after two weeks of intensified training. Int J Sports Med. 1992;13(7):534-41.

21. Brechtel LM, Braumann KM, Wolff R. Time course of symptoms during the development of a parasympathetic overt- raining syndrome [abstract]. Med Sci Sports Exerc. 1999;31 Suppl:S176.

22. Lehmann M, Foster C, Keul J. Overtraining in endurance athletes: a brief review. Med Sci Sports Exerc 1993;25(7): 854-62

23. Lehmann M, Petersen KG, Liu Y, Gastmann U, Lormes W, Steinacker JM. [Chronic and exhausting training in sports -influence of leptin and inhibin]. Dtsch Z Sportmed. 2001;51:234-43.

24. Urhausen A, Gabriel H, Kindermann W. Blood hormones as markers of training stress and overtraining Sports Med. 1995;20(4):251-76.

25. Urhausen A, Gabriel H, Weiler B, Kindermann W. Ergometric and psychological findings during overtraining a long-term follow-up study in endurance athletes. Int J Sports Med. 1998;19(2):114-20.

26. Gouarné C, Groussard C, Gratas-Delamarche A, Delamarche P, Duclos M. Overnight urinary cortiso and cortisone add new insights into adaptation to training. Med Sci Sports Exerc. 2005;37(7):1157-67.

27. Kern W, Perras B, Wodick R, Fehm HL, Born J. Hormonal secretion during nighttime sleep indicating stress of daytime exercise. J Appl Physiol (1985). 1995;79(5):1461-8.

28. Duclos M. A critical assessment of hormonal methods used in monitoring training status in athletes. Int Sport Med J. 2008;9(2):56-66.

29. Gabriel H, Kindermann W. The acute immune response to exercise: what does it mean? Int I Sport Med. 1997;18(Suppl 1):S28-45.

30. Margonis K, Fatouros IG, Jamurtas AZ, Nikolaidis MG, Douroudos I, Chatznikolaou A, et al. Oxidative stress biomarkers responses to physical overtraining: implications for diagnosis. Free Radic Biol Med 2007:43(6):901-10 